\title{
Analysis of Dimension Stone Waste Addition to the Clayey Mass Used in Roof Tile Production
}

\author{
Alessandra Savazzini dos Reis ${ }^{a *}$, Viviana Possamai Della-Sagrillo ${ }^{b}$, \\ Francisco Rolando Valenzuela-Diaz ${ }^{c}$ \\ ${ }^{a}$ Instituto Federal do Espirito Santo, Avenida Arino Gomes Leal, 1700, Santa Margarida, \\ CEP 29700-660, Colatina, ES, Brazil \\ ${ }^{b}$ Instituto Federal do Espírito Santo, Avenida Vitória, 1729, Jucutuquara, \\ CEP 29040-780, Vitória, ES, Brazil \\ ${ }^{c}$ Departament of Metalurgical and Materials Engineering, Universidade de São Paulo - USP, \\ Avenida Professor Mello Moraes, 2463, Butantã, CEP 05508-030, São Paulo, SP, Brazil
}

Received: November 7, 2014; Revised: November 18, 2015

\begin{abstract}
Addition of dimension stone waste to clayey mass is an alternative to make the dimension stone sector more environmentally sustainable and to reduce the consumption of clayey raw material. Our aim is to study the technical feasibility of dimension stone waste addition to the clayey mass used in roof tile production. Samples of waste and clay were tested for physical, chemical, mineralogical and microstructural characterization. Samples containing dimension stone waste contents, varying from $10 \%$ to $90 \%$ (wt.), were produced and burned in industrial furnace of a structural ceramic factory at a $900^{\circ} \mathrm{C}$ maximum temperature for 24 hours. The technological characteristics evaluated were water absorption, apparent porosity, apparent density, loss on ignition, linear shrinkage and flexural strength. The results show that the samples with up to $60 \%$ waste content can be used in the production of ceramic bodies, since the waste promoted the physical packing of the grains, which increased the densification of ceramic bodies. With that, the waste-improved ceramic characteristics were analyzed. From $60 \%$ content onwards, the waste was not be able to fill the remaining interstices between the clay grains to densify the ceramic body because both raw materials have similar particle size distribution. Furthermore, the excess silica, in the form of quartz contained in the waste, presents an inert behavior in the factory firing temperature used in this research, causing fracture points and decreasing the flexural strength.
\end{abstract}

Keywords: waste, dimension stones waste, structural ceramic, ceramic roof tile

\section{Introduction}

The dimension stones factory has greatly developed over the years and presents a great increase in production. According to the Associação Brasileira da Indústria de Rochas Ornamentais - ABIROCHAS ${ }^{1}$, around 2.7 million tons of dimension stones were exported in 2013, and the participation of the processed stones in the physical export volume was $47.0 \%$.

The state of Espírito Santo, in the southeast region of Brazil, stands out as the main producer and the greatest processor and exporter of dimension stones in Brazil, accounting for $64.5 \%$ of the Brazilian stones production with the other states in the region.

Dimension stone processing generates waste that can cause undesirable environmental impacts, especially if improperly disposed. Sawing dimension stone blocks into plates in the looms of metallic blades generates waste in the form of mud containing stone powder, steel grit, lime and water. After drying, the mud produces a large volume of very fine powder due the great industrial production, which represents

*e-mail: alessandrar@ifes.edu.br about $30 \%$ of the block volume ${ }^{2}$. In 2013, 3.7 million tons of waste were generated from stone processing ${ }^{1}$ in Brazil.

Waste reuse is a way to make the dimension stone industry more environmentally sustainable, minimizing disposal in landfills, or avoiding improper disposal, which can cause soil, air and water contamination.

Furthermore, clayey materials used in the structural ceramic industry show an extensive range of compositions, allowing the incorporation of a variety of industrial waste materials, such as dimension stone waste.

The literature presents studies on the use of dimension stone waste in structural ceramic clayey masses ${ }^{3-10}$ with contents varying from $10 \%$ to $60 \%$ (wt.). The technical feasibility of using waste in the researches was based on results from water absorption, apparent porosity and mechanical strength in specimens fired at temperatures ranging from $800^{\circ} \mathrm{C}$ to $1150^{\circ} \mathrm{C}$ in laboratory furnaces in which the temperature varies linearly. The improvements in characteristics occurred in contents varying from $10 \%$ to $40 \%$ of waste ${ }^{3-10}$. Besides the research into the use of dimension stone waste in structural ceramic products, several applications can be cited, such 
as cement mortar, porcelain, lime-silica brick, soil-cement brick, concrete, asphalt, cement industry, plastic and rubber industry, tactile floor hydraulic tile ${ }^{11}$ and agriculture. The author emphasizes that most researches with dimension stone waste failed to become technological innovations ${ }^{11}$. This problem needs to be solved by approaching academic research to the productive sector.

We therefore aim to study the technical feasibility of dimension stone waste addition to the clayey mass used in roof tile production. The research was conducted at the factory to reduce the research time from laboratory to large-scale production test. With that, the research took into consideration the firing temperature and the same conditions used in the industry for manufacturing roof tiles. Based on the results, roof tiles will be thereafter produced at the factory with the tested mixture.

\section{Material and Methods}

The clay is extracted from a quarry located in Itapina-ES-Brazil. The waste is generated in a cutting and polishing dimension stones industry located in Colatina-ES-Brazil.

The clay and waste do not undergo any type of treatment before entering the structural ceramic production. The iron particles from saws were not removed from the dimension stones waste. Samples of clay and dimension stone waste were collected directly from storage piles of the structural ceramic factory located in Colatina-ES, using waste sampling procedures specified by the Brazilian Standard NBR 10007/2004 ${ }^{[12]}$ (Sampling of Solid Waste) After that, the samples were air-dried, broken with the aid of a pounder, homogenized and quartered. Part of the material was used for characterization tests, and part for preparing the specimens.

The materials were characterized by X-ray fluorescence (XRF) in a Philips PW2400 spectrometer; X-ray diffraction
(XRD) with copper source ( $\mathrm{K} \alpha$ radiation) in Philips X-Pert MPD equipment; scanning electron microscopy (SEM) in a Philips XL-30 electron microscope; particle size analysis by laser diffraction in Malvern Mastersizer 2000 equipment. And the plasticity was evaluated using Atterberg's consistency limits ${ }^{13,14}$.

The materials were sieved in ABNT (Brazilian Association of Technical Standards) \# 80; mixtures of clay with dimension stone waste in contents varying from $10 \%$ to $90 \%$ (weight) and solely of clay ( $0 \%$ waste) were prepared.

Prismatic specimens (bars) were made (Figure 1), measuring $20 \mathrm{~mm} \times 60 \mathrm{~mm} \times 5 \mathrm{~mm}$ by axial pressing at $250 \mathrm{kgfcm}^{-2}$ according to Souza Santos's methodology ${ }^{15,16}$. The bars were oven dried for 24 hours at $110^{\circ} \mathrm{C}$ and the flexural strength was measured. Part of the bars was burned for 24 hours in an industrial tunnel-type furnace in a structural ceramic factory at a maximum $900^{\circ} \mathrm{C}$ temperature in the burning zone for about 6 hours. The burning of the bars was performed in the ceramic factory to simulate the real variation in temperature of a furnace, which will be used for producing the roof tiles with the test mixture.

After firing, the following characteristics were evaluated: water absorption, apparent porosity, apparent density, flexural strength, linear shrinkage and loss on ignition in bars according to Santos ${ }^{15,16}$.

\section{Results and Discussion}

\subsection{Chemical and mineralogical characterization of raw materials}

The chemical analysis in Table 1 shows that the clay presents typical chemical composition of clayey raw material, with a predominance of silica and alumina, with values of $43.39 \%$ and $30.16 \%$, respectively. These contents are within

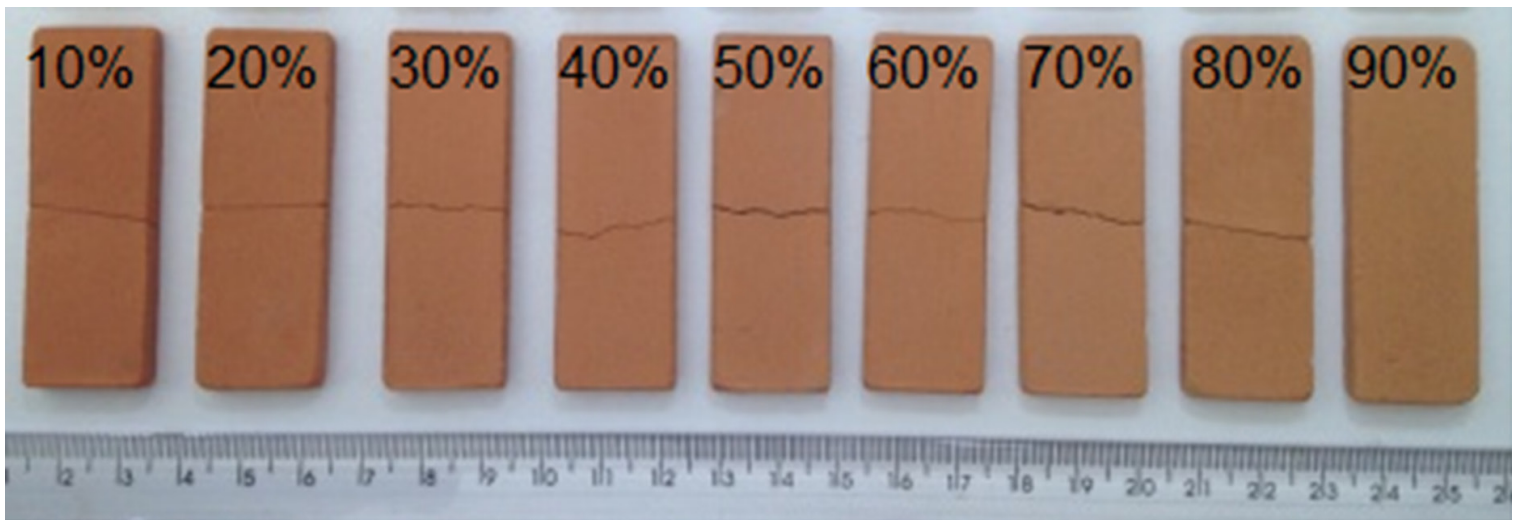

Figure 1. Examples of burned bars of clayey mass with dimension stone waste (after rupture) with contents from $10 \%$ to $90 \%$ (wt) after rupture.

Table 1. Chemical composition of clay and dimension stone waste by XRF.

\begin{tabular}{cccccccccccc}
\hline \multicolumn{10}{c}{ Composition expressed in oxides (\% wt) } \\
\hline & $\mathbf{S i O}_{2}$ & $\mathbf{A l}_{\mathbf{2}} \mathbf{O}_{\mathbf{3}}$ & $\mathbf{F e}_{\mathbf{2}} \mathbf{O}_{\mathbf{3}}$ & $\mathbf{T i O}_{2}$ & $\mathbf{K}_{\mathbf{2}} \mathbf{O}$ & $\mathbf{M g O}$ & $\mathbf{P}_{2} \mathbf{O}_{\mathbf{5}}$ & $\mathbf{N a}_{\mathbf{2}} \mathbf{O}$ & $\mathbf{C a O}$ & $\mathbf{B a O}$ & $\mathbf{L O I}$ \\
\hline Clay & 43.39 & 30.16 & 9.29 & 1.39 & 1.25 & 0.62 & 0.12 & 0.17 & 0.24 & - & 13.17 \\
Waste & 62.88 & 14.11 & 5.72 & 0.67 & 4.36 & 1.02 & 0.38 & 2.54 & 4.42 & 0.22 & 2.97 \\
\hline
\end{tabular}

LOI: loss on ignition. 
the ranges from $43.20 \%$ to $77.60 \%$ for silica and from $6.80 \%$ to $38.00 \%$ for alumina ${ }^{15,16}$ and indicate the presence of kaolinite ${ }^{10,15}$. The $9.29 \%$ iron oxide is responsible for the reddish color after firing. The non-significant value of $\mathrm{K}_{2} \mathrm{O}(1.25 \%)$ found in the XRF indicates the presence of illite; a fact also reported by Taguchi et al. ${ }^{10}$. Furthermore, the concentration of $\left(\mathrm{Na}_{2} \mathrm{O}+\mathrm{K}_{2} \mathrm{O}=1.42 \%\right)$ is not high; therefore, even being fluxing oxides, they contribute little to the formation of the glassy phase during firing. The clay in question is silica-aluminous, with high iron content and low fluxing oxides content, requiring high sintering temperatures ${ }^{17}$. The value of $13.17 \%$ loss on ignition is in the range of $6.00 \%$ to $15.70 \%$, required by Santos ${ }^{15,16}$, specific for clayey raw material of structural ceramic, indicating that there was burning of organic matter and possible decomposition of carbonate. Characteristics, such as high amount of kaolinite clay mineral, high loss on ignition, presence of hydroxides, small amount alkaline fluxes can lead to a refractory clay behavior which can impair sintering during the firing process ${ }^{18}$.

The chemical analysis of the waste showed it is a silica-aluminous material. The high amount of $\mathrm{SiO}_{2}(62.88 \%)$ is associated to the crystalline phase of quartz. The waste added to the clay can help change the plasticity and improve the clay drying step due to its high content of free silica ${ }^{19}$. However, excess quartz may hinder extrusion and reduce the dry mechanical strength; at the firing step, it may behave as an inert phase and generate microcracks, due to the allotropic transformation of quartz around $573^{\circ} \mathrm{C}^{[19]}$. Therefore, the amount of silica present in the waste is to be taken into consideration to prevent the problems mentioned. The presence of alkaline oxides in the waste $\left(\mathrm{Na}_{2} \mathrm{O}+\mathrm{K}_{2} \mathrm{O}=6.93 \%\right)$ can contribute to burning ceramic bodies because they are fluxing oxides. The presence of $\mathrm{Fe}_{2} \mathrm{O}_{3}$ is associated to steel grit; and $\mathrm{CaO}$, which can act as fluxing ${ }^{19}$, associated to lime, both used in the mud. The waste has low loss on ignition in relation to the clay, which means dimensional stability of waste for heat treatment. The low value of loss on ignition and the high contents of silica and alumina suggest that the stone is granitic ${ }^{4}$.

The X-ray diffraction of the raw materials is shown in Figure 2. The XRD of clay indicates that the predominant clay mineral is kaolinite, which corroborates the result of $\mathrm{XRF}$, because clay with a high content of $\mathrm{Al}_{2} \mathrm{O}_{3}$ and a low percentage of fluxing oxides generally presents kaolinite as its main clay mineral ${ }^{10}$. Peak characteristics were also detected: illite, goethite (probably due to the high $\mathrm{Fe}_{2} \mathrm{O}_{3}$ content); and quartz.

In the case of waste, XRD indicates the presence of quartz, feldspar, mica and calcite: main mineral constituents of dimension stones ${ }^{19}$. The primary minerals, mica and feldspar found in the waste have $\mathrm{K}_{2} \mathrm{O}$ e $\mathrm{Na}_{2} \mathrm{O}$ in the composition, the oxides accounting for the formation of the liquid phase.

The crystalline phases identified in the raw materials are in agreement with the results from the XRF (Table 1).

\subsection{Physical and microstructural characterization of raw materials}

Atterberg limits on the raw materials are presented in Table 2. The clay plasticity index (PI) is $21.2 \%$, above $15.0 \%$, indicating high plasticity, which makes it suitable for molding by extrusion. However, this amount of clay PI can lead to a larger amount of water necessary for extruding pieces, thus requiring longer drying. Regarding the plasticity limit (PL), the $38.4 \%$ value is within the range from $9.0 \%$ to $56.0 \%$ specified by Santos ${ }^{15,16}$ for kaolinitic clay, confirming the predominance of the kaolinite mineral identified in XRD.

Attempts were made to determine the plasticity limit of dimension stone waste, but the experiments were not successful, as in the work by Moreira et al. ${ }^{4}$. Therefore, the waste is not a plastic material, which can contribute to achieving ideal plasticity of the mixture in the extruder.

The particle size distribution of the clay and the waste are shown in Figure 3. The effective diameter of the clay is $2.9 \mu \mathrm{m}$ and the waste is $2.2 \mu \mathrm{m}$. These are very close values, indicating that both raw materials have similar particle size distribution. The clay and the dimension stone waste have about $40 \%$ grains larger than $20 \mu \mathrm{m} ; 50 \%$ grains between $2 \mu \mathrm{m}$ and $20 \mu \mathrm{m}$, and less than $10 \%$ grains smaller than $2 \mu \mathrm{m}$. The clay has low "clay fraction" (grains smaller than $2 \mu \mathrm{m}$ ), presenting plasticity due to the organic matter contained in the clay.

Figure 4 presents images showing the material morphology and particle size obtained by electron microscopy. The images show that the grains are irregular in shape tending to form slender and lamellar particles, some scattered and others in clumps forming larger particles. The formation of these clumps between very thin particles may increase the porosity of the ceramic bodies ${ }^{20}$. The grain size ranged from $2 \mu \mathrm{m}$ to $46 \mu \mathrm{m}$ in the clay; and from $2 \mu \mathrm{m}$ to $42 \mu \mathrm{m}$ in dimension stone waste.

\subsection{Ceramic characterization}

The ceramic characteristics obtained from the specimens of clayey mass with dimension stone waste in contents $0 \%$, $10 \%, 20 \%, 30 \%, 40 \%, 50 \%, 60 \%, 70 \%, 80 \%$ and $90 \%(w t)$

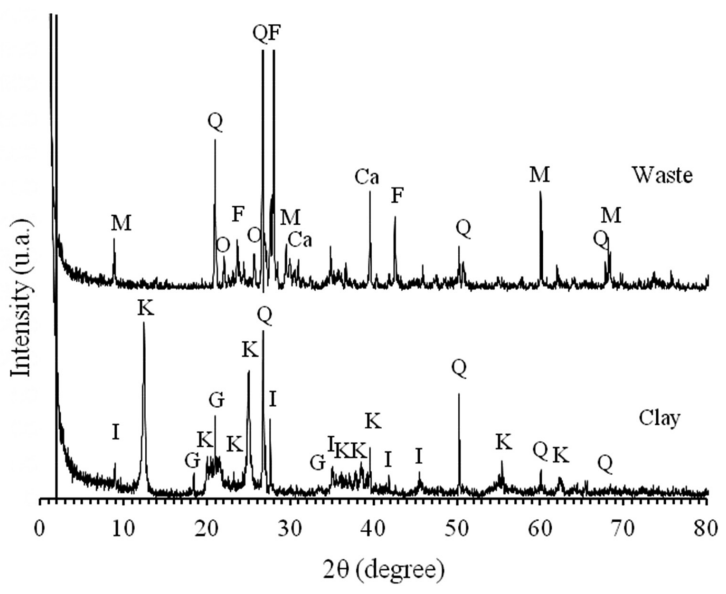

Figure 2. XRD of clay and dimension stone waste.

Table 2. Atterberg limits of clay and dimension stone waste.

\begin{tabular}{cccc}
\hline & $\begin{array}{c}\text { Plasticity } \\
\text { Limit-PL (\%) }\end{array}$ & $\begin{array}{c}\text { Liquid Limit- } \\
\text { LL (\%) }\end{array}$ & $\begin{array}{c}\text { Plasticity } \\
\text { Índex-PI (\%) }\end{array}$ \\
\hline Clay & 38.4 & 59.6 & 21.2 \\
Waste & n.d. & 28.1 & n.d. \\
\hline
\end{tabular}

n.d.: not determined. 


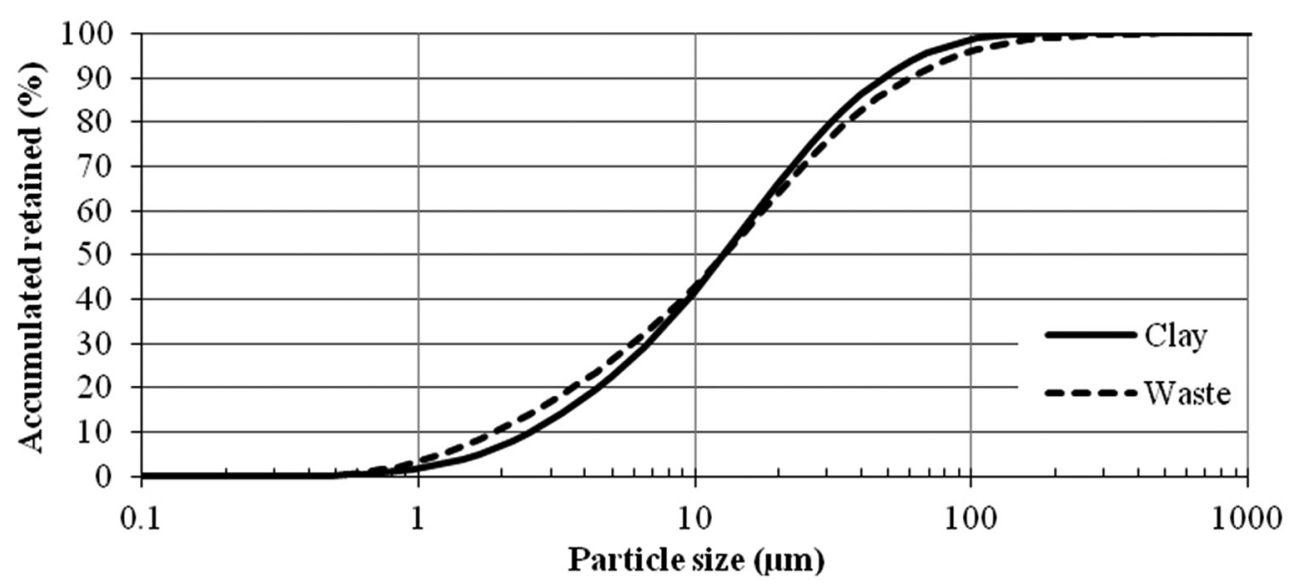

Figure 3. Particle size distribution curve of of clay and dimension stone waste.

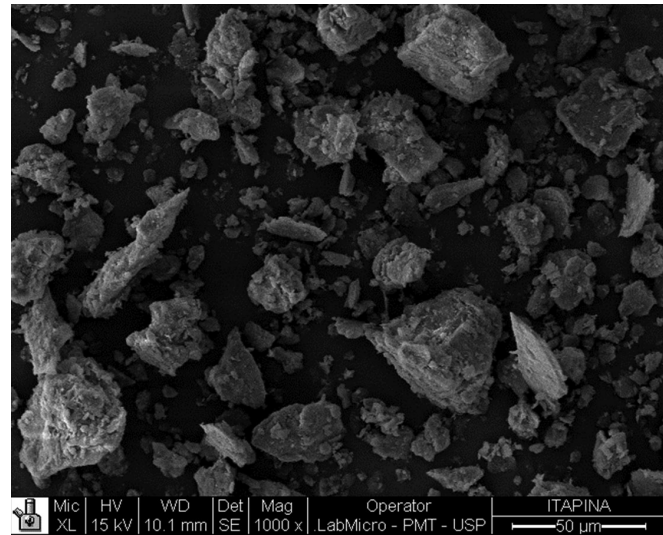

(a) Clay $-1000 \mathrm{x}$

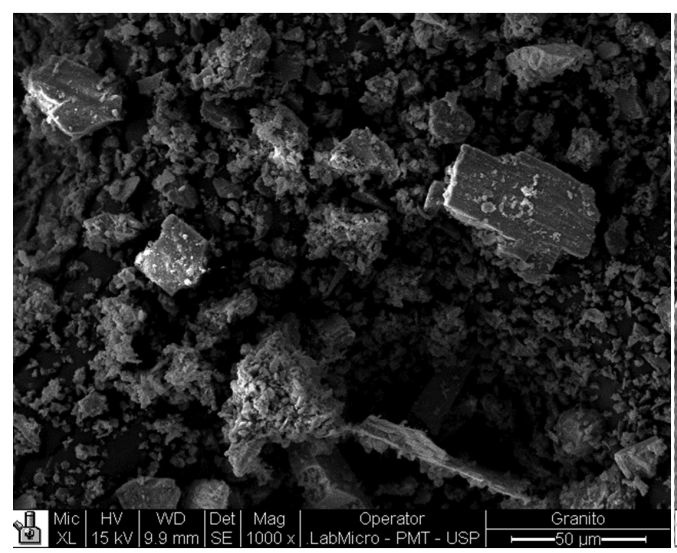

(c) Waste $-1000 \mathrm{x}$

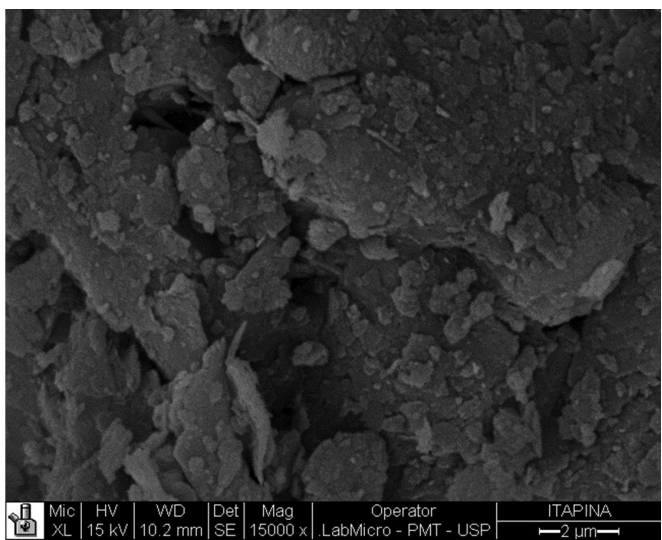

(b) Clay - $15000 \mathrm{x}$

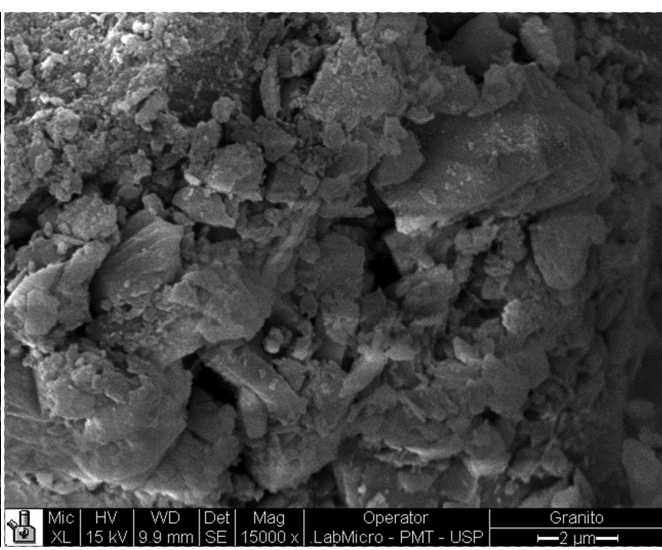

(d) Waste - 15000x

Figure 4. SEM of (a) clay - 1000x; (b) clay - 15000x; (c) dimension stone waste - 1000x; (d) dimension stone waste - 15000x.

are shown in Figures 5-8 and are summarized in Table 3, which presents the average and standard deviation of the values obtained.

Figure 5 shows the behavior of the loss on ignition (LOI) and the linear shrinkage (LS) of the clayey specimens with the addition of waste. The loss on ignition and linear shrinkage values decreased with the increasing content of waste. Thus, the waste promoted greater dimensional stability to ceramic bodies, because it contains high silica content, which may result in crack reduction due to shrinkage, corroborating the work by Rodrigues et al. ${ }^{9}$ and Taguchi et al. ${ }^{10}$.

Figure 6 shows the behavior of water absorption (WA) and apparent porosity (AP) of the clayey specimens with waste addition. As expected, the results for water absorption 


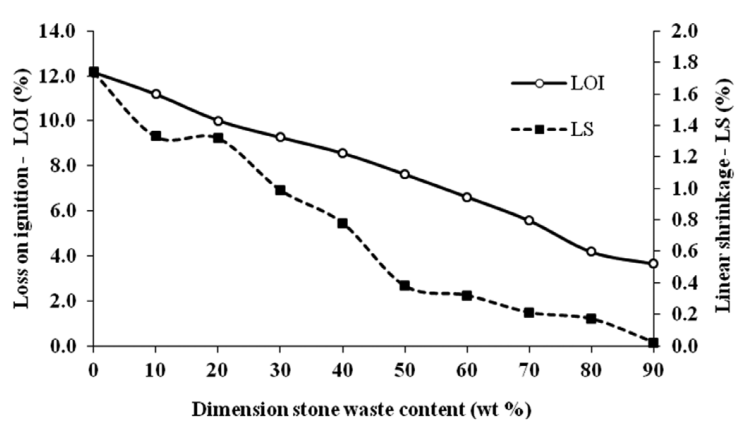

Figure 5. Loss on ignition (\%) and linear shrinkage (\%) as a function of dimension stone waste content (\%).

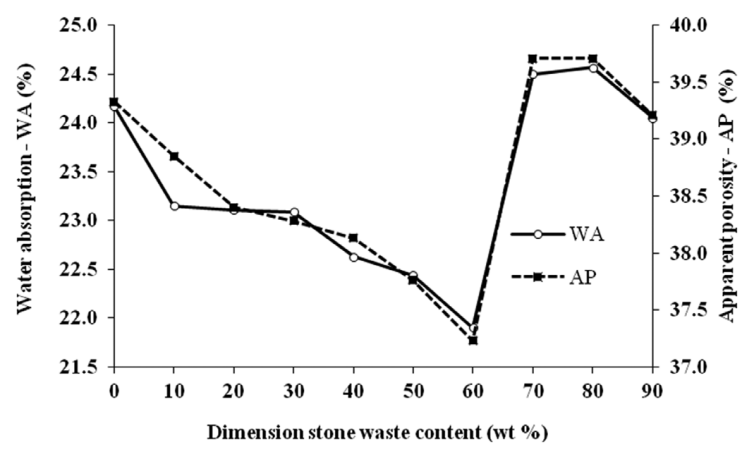

Figure 6. Water absorption (\%) and apparent porosity (\%) as a function of dimension stone waste content (\%).

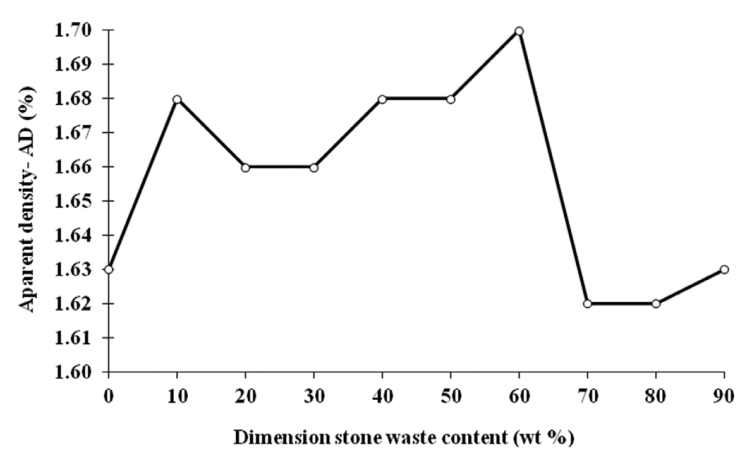

Figure 7. Apparent density $\left(\mathrm{gcm}^{-3}\right)$ as a function of dimension stone waste content $(\%)$.

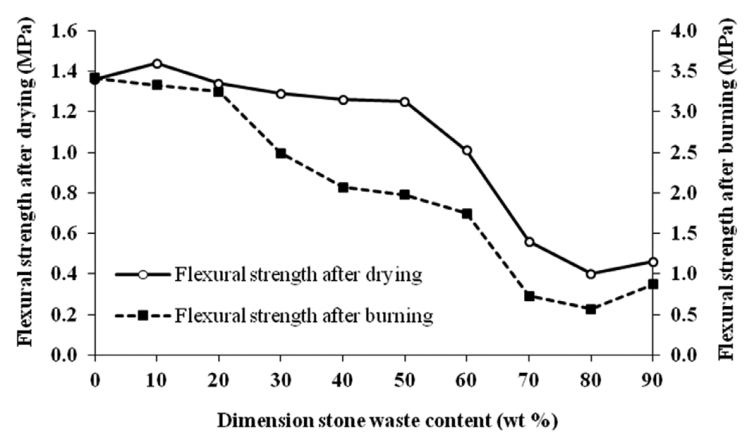

Figure 8. Flexural strength after drying $(\mathrm{MPa})$ and flexural strength after burning (MPa) as a function of dimension stone waste content $(\%)$. present the same behavior observed for apparent porosity once those characteristics were dependent. The water absorption and apparent porosity values decreased with the increase in waste content, showing the main effect of the waste on the densification of the ceramic body. This happened up to $60 \%$ waste, in which minimum percentage of water absorption and apparent porosity was obtained.

As from $60 \%$, the waste was not be able to fill the remaining interstices between the clay grains to densify the ceramic body seeing that both raw materials have similar particle size distribution. Thus, there was no physical packing of the grains or the expected densification. Water absorption met the maximum limit of $25 \%$ specified for Brazilian standard clays $^{15,16}$, while apparent porosity did not meet the maximum limit of $35 \% \%^{[15,16]}$.

Figure 7 allows observing that the apparent density (AD) presented maximum value of $1.70 \mathrm{gcm}^{-3}$ for $60 \%$ waste, confirming the samples maximum densification. This had been observed before with the minimum values found for absorption and porosity at $60 \%$ waste.

Table 3 shows that the apparent density values ranged from $1.62 \mathrm{gcm}^{-3}$ to $1.70 \mathrm{gcm}^{-3}$, according to the $1.50 \mathrm{gcm}^{-3}$ to $2.00 \mathrm{gcm}^{-3}$ range prescribed by Santos ${ }^{15,16}$ for clayey mass used in structural ceramic.

Figure 8 presents the flexural strength behavior of the specimens, both dried and burned. With the addition of the dimension stone waste in ceramic bodies, the flexural strength of dried and burned specimens decreased. This occurred since the excess silica in the form of quartz contained in the waste presents an inert behavior at the industrial firing temperature used in this research. Thus, quartz causes fracture points decreasing the flexural strength in the specimens with high waste content. Low flexural strength in ceramic bodies is also attributed to the presence of quartz from the dimension stone waste according to some authors ${ }^{8,19,21,22}$.

Table 3 shows that the flexural strength in the specimens dried up to $70 \%$ waste content meet the Brazilian standard clays $^{15,16}$ to be used in structural ceramics, from 0.50 MPa to 7.00 MPa. However, the flexural strength of burned specimens did not meet the minimum value of $6.00 \mathrm{MPa}^{[15,16]}$. Despite the unsatisfactory results of flexural strength after burning, comparing the values obtained from specimens made solely of clay with mixtures containing waste, there appears to have been improvements, confirming the beneficial action of waste in the ceramic bodies.

Another factor that may have influenced the low values of flexural strength of the burned specimens is the low firing temperature (maximum $900^{\circ} \mathrm{C}$ ), which is not sufficient to complete the glassy phase formation, not influencing the decrease in porosity. The influence of temperatures below $900^{\circ} \mathrm{C}$ in porosity was also observed by Pinheiro \& Holanda ${ }^{22}$, which recommend that this firing temperature is more favorable for manufacturing blocks instead of roof tile.

With the maximum burning temperature of $900^{\circ} \mathrm{C}$ tested for this work, sintering occurred by solid diffusion ${ }^{18}$, due to the greater number of contacts between the clay and waste fine particles and to the physical packing between the grains, which is confirmed by other studies ${ }^{8,18,23,24}$. 
Table 3. Ceramics characteristics of clayey mass with dimension stone waste in contents ranging from $10 \%$ to $90 \%$ and solely of clay $(0 \%)$ - averages and standard deviations.

\begin{tabular}{|c|c|c|c|c|c|c|c|}
\hline Ref. & - & $\leq 25$ & $\leq 35$ & 1.5 to 2.0 & 2 to $17 *$ & 0.5 to 7.0 & $>6.0$ \\
\hline Waste (\%) & $\begin{array}{l}\text { LOI } \\
(\%)\end{array}$ & $\begin{array}{l}\text { WA } \\
(\%)\end{array}$ & $\begin{array}{l}\text { AP } \\
(\%)\end{array}$ & $\underset{\left(\mathrm{g} / \mathrm{cm}^{3}\right)}{\mathbf{A D}}$ & $\begin{array}{l}\text { LS } \\
(\%)\end{array}$ & $\begin{array}{c}F_{\mathrm{DS}_{\mathrm{D}}} \\
(\mathrm{MPa})\end{array}$ & $\begin{array}{c}F_{\mathbf{B}_{\mathrm{B}}} \\
(\mathrm{MPa})\end{array}$ \\
\hline 0 & $12.16 \pm 0.17$ & $24.17 \pm 1,24$ & $39.33 \pm 1.90$ & $1.63 \pm 0.02$ & $1.74 \pm 0.11$ & $1.36 \pm 0.14$ & $3.42 \pm 0.31$ \\
\hline 10 & $11.19 \pm 0.08$ & $23.15 \pm 1.33$ & $38.85 \pm 0.01$ & $1.68 \pm 0.04$ & $1.33 \pm 0.14$ & $1.44 \pm 0.01$ & $3.33 \pm 0.27$ \\
\hline 20 & $10.02 \pm 0.02$ & $23.11 \pm 0.81$ & $38.40 \pm 0.01$ & $1.66 \pm 0.04$ & $1.32 \pm 0.05$ & $1.34 \pm 0.11$ & $3.25 \pm 0.65$ \\
\hline 30 & $9.27 \pm 0.02$ & $23.09 \pm 1.52$ & $38.28 \pm 0.01$ & $1.66 \pm 0.08$ & $0.99 \pm 0.12$ & $1.29 \pm 0.07$ & $2.49 \pm 0.31$ \\
\hline 40 & $8.57 \pm 0.12$ & $22.63 \pm 0.04$ & $38.13 \pm 0.01$ & $1.68 \pm 0.03$ & $0.78 \pm 0.12$ & $1.26 \pm 0.00$ & $2.07 \pm 0.38$ \\
\hline 50 & $7.63 \pm 0.12$ & $22.44 \pm 0.34$ & $37.76 \pm 0.00$ & $1.68 \pm 0.03$ & $0.38 \pm 0.18$ & $1.25 \pm 0.18$ & $1.98 \pm 0.46$ \\
\hline 60 & $6.62 \pm 0.21$ & $21.90 \pm 0.01$ & $37.23 \pm 0.01$ & $1.70 \pm 0.03$ & $0.32 \pm 0.24$ & $1.01 \pm 0.11$ & $1.75 \pm 0.08$ \\
\hline 70 & $5.57 \pm 0.53$ & $24.50 \pm 0.01$ & $39.71 \pm 0.01$ & $1.62 \pm 0.02$ & $0.21 \pm 0.14$ & $0.56 \pm 0.22$ & $0.73 \pm 0.19$ \\
\hline 80 & $4.18 \pm 0.18$ & $24.57 \pm 0.01$ & $39.71 \pm 0.01$ & $1.62 \pm 0.00$ & $0.17 \pm 0.05$ & $0.40 \pm 0.00$ & $0.57 \pm 0.04$ \\
\hline 90 & $3.65 \pm 0.71$ & $24.05 \pm 0.01$ & $39.21 \pm 0.01$ & $1.63 \pm 0.03$ & $0.02 \pm 0.03$ & $0.46 \pm 0.01$ & $0.87 \pm 0.07$ \\
\hline
\end{tabular}

Ref.: reference values ${ }^{15,16}$; LOI: loss on ignition; WA: water absorption; AP: apparent porosity; AD: apparent density; LS: linear shrinkage; FSD: flexural strength dry; FSB: flexural strength burning. *values for kaolinite clays ${ }^{15,16}$.

\section{Conclusions}

The chemical and mineralogical characterization of clay, proved to be predominantly kaolinitic, containing suitable quartz and iron contents and it may have refractory behavior. The clay and the dimension stone waste may be considered silica-aluminous materials; the waste still contains fluxing oxides that can assist in the ceramic bodies firing process. The clay has high plasticity, while the waste is not a plastic material. Both raw materials have similar particle size distribution, and grains are irregular in shape, some scattered and others in clumps. The results show that the samples with up to $60 \%$ waste content are proper for being used in the production of ceramic bodies, since the waste promoted the physical packing of the grains, which increased the densification of ceramic bodies. With that, the waste improved the ceramic characteristics analyzed. From the $60 \%$ content onwards, the waste was not be able to fill the

\section{References}

1. Associação Brasileira da Indústria de Rochas Ornamentais - ABIROCHAS. Balanço das exportações e importações brasileiras de rochas ornamentais em 2013. Inf. 01/2014. São Paulo: ABIROCHAS; 2014. Available from: <http://www. ivolution.com.br/mais/fotos/6/17/3050/Informe_01_2014.pdf $>$. Access in: 15 Aug 2014.

2. Reis AS and Alvarez CE. A sustentabilidade e o resíduo gerado no beneficiamento das rochas ornamentais. In: Anais II Encontro Latino Americano de Edificações e Construções Sustentáveis - II ELECS; 2007; Campo Grande, Brasil. Porto Alegre: ANTAC; 2007. CD-ROM.

3. Neves GA. Reciclagem de resíduos da serragem de granitos para uso como matéria-prima cerâmica. [Thesis]. Campina Grande: Universidade Federal de Campina Grande; 2002.

4. Moreira JMS, Freire MN and Holanda JNF. Utilization of granite sawing waste from Espírito Santo state in red ceramic. Cerâmica. 2003; 49:262-267.

5. Vieira CMF, Peçanha LA and Monteiro SN. Efeito da incorporação de resíduo de serragem de granito em massa de cerâmica vermelha. Vértices. 2003; 5(3):143-157. remaining interstices between the clay grains to densify the ceramic body due both raw materials having similar particle size distribution. Additionally, the excess silica, in the form of quartz contained in the waste, presents an inert behavior at the factory firing temperature used in this research, which causes fracture points and decreases the flexural strength.

It also confirms the need to increase the firing temperature to reduce porosity, to form the liquid phase to dissolve the quartz, resulting in increased flexural strength of ceramic bodies.

The approach used herein, performed with the actual manufacturing conditions, can be said to greatly facilitate the passage from laboratory studies to industrial scale.

\section{Acknowledgements}

The authors thank IFES and USP/PMT.

6. Silva JB, Hotza D, Segadães AM and Acchar W. Incorporation of marble and granite sludge in clay materials. Cerâmica. 2005; 51:325-330.

7. Acchar W, Vieira FA and Hotza D. Effect of marble and granite sludge in clay materials. Materials Science and Engineering. 2006; 419(1-2):306-309. http://dx.doi.org/10.1016/j.msea.2006.01.021.

8. Manhães JPVT, Moreira JMS and Holanda JNF. Microstructural variation of red ceramic incorporated with ornamental rock waste. Cerâmica. 2009; 55:371-378

9. Rodrigues DV, Xavier GC, Saboya F, Maia PCA and Alexandre J. Durabilidade de peças cerâmicas vermelhas com adição de rejeito de rochas ornamental isenta de granalha. Cerâmica. 2012; 58(347):286-293. http://dx.doi.org/10.1590/S036669132012000300003 .

10. Taguchi SP, Santos JC, Gomes TM and Cunha NA. Evaluation of technological properties of red ceramics incorporated with dimension Stones waste from diamond wire loom. Cerâmica. 2014; 60:291-296. http://dx.doi.org/10.1590/S036669132014000200020 .

11. Reis AS. Estudo do aproveitamento do resíduo de beneficiamento de rochas ornamentais na fabricação de ladrilho hidráulico 
piso tátil. [Dissertation]. Vitória: Universidade Federal do Espírito Santo; 2008.

12. Associação Brasileira de Normas Técnicas-ABNT. ABNTNBR 10007:2004, sampling of solid waste. Rio de Janeiro. 2004.

13. Associação Brasileira de Normas Técnicas-ABNT. ABNTNBR 6459, soil - determination of the liquid limit. Rio de Janeiro: ABNT; 1984.

14. Associação Brasileira de Normas Técnicas-ABNT. ABNTNBR 7180, soil - determination of the plastic limit. Rio de Janeiro: ABNT; 1984.

15. Santos PS. Tecnologia das argilas. São Paulo: Edgard Blucher; 1975. v. 1.

16. Santos PS. Tecnologia das argilas. São Paulo: Edgard Blucher; 1975. v. 2.

17. Hildebrando EA, Souza JAS, Angelica RS and Neves RF. Application of bauxite waste from Amazon Region in the heavy clay industry. Materials Research. 2013; 16(6):1418-1422. http://dx.doi.org/10.1590/S1516-14392013005000145.

18. Borlini MC, Pazeto AA, Correa JCG, Reis AS and Caranassios A. Characterization of waste from dimension stones processing. In: Proceedings of the 2nd International Congress Dimension Stones; 2009; Carrara, Itália. Pisa: Pacini; 2009. p. 407-410.
19. Oliveira IR, Studart AR, Pileggi RG and Pandolfelli VC. Dispersão e empacotamento de partículas -princípios e aplicações em processamento cerâmico. São Paulo: Fazendo Arte Editorial; 2000.

20. Aguiar MC. Utilização de resíduos de serragem de rocha ornamental com tecnologia de fio diamantado em cerâmica vermelha. [Dissertation]. Campos dos Goytacazes: Universidade Estadual do Norte Fluminense; 2012.

21. Pazeto AA, Borlini MC and Caranassois A. Caracterização do resíduo proveniente do beneficiamento do granito Iberê Crena Bordeaux e sua aplicação em cerâmica argilosa. In: Anais da XVI Jornada de Iniciação Científica do CETEM; 2008; Rio de Janeiro, Brasil. Rio de Janeiro: CETEM; 2008. p. 134-140.

22. Pinheiro BCA and Holanda JNF. Effect of the firing temperature on some mechanical properties of red ceramic. Cerâmica. 2010; 56(339):237-243. http://dx.doi.org/10.1590/S036669132010000300005 .

23. Moreno MMT, Bartolomeu D and Lima RH. Analysis of the firing behavior of clays and formulations for ceramic tiles. Cerâmica. 2009; 55:286-295.

24. Milheiro FAC, Freire MN, Silva AGP and Holanda JNF. Densification behavior of a red firing Brazilian kaolinitic clay. Ceramics International. 2005; 31(5):757-763. http://dx.doi. org/10.1016/j.ceramint.2004.08.010. 